\title{
Project management effectiveness as a construct: A conceptual study
}

\author{
J. Morrison and C. Brown* \\ Graduate School of Business, University of Stellenbosch, \\ PO Box 610, Bellville 7535, Republic of South Africa
}

\author{
Received May 2004
}

\begin{abstract}
Project management has grown from being mainly a tool for large single projects, to being used by organizations for running multiple smaller projects on an ongoing basis. Since this trend has caused scholarly attention to expand from studying the project itself, to focusing on the organization's project management capability, the absence of a coherent proposition of effective project management becomes evident. This study addresses and conceptually explores this shortcoming by blending success concepts in project management with the theory of organizational effectiveness, to propose a framework of project management effectiveness. The result is a multi-dimensional construct that has substantial support from the project management success literature and that compares well with the open systems thinking of organizational effectiveness. A selected group of project management experts gave strong support to the list of variables established to define the domain of such a construct.
\end{abstract}

*To whom all correspondence should be addressed.

\section{Introduction}

The subject of project management lacks a clearly defined and accepted concept of effectiveness, similar to how organizational effectiveness has been used in the description of success and performance in organizations. This paper aims to fill that gap by combining organizational effectiveness theories, with success concepts in the project management literature, to propose a construct of project management effectiveness. The use of the word construct implies the specific interest to postulate a concept for measurement in scientific studies (Kerlinger, 1986:27).

Project management studies through the years have extensively addressed topics related to both project success determinants and project success measurement, but have not shown adequate convergence of these into a consolidated and theoretically accepted construct of project management effectiveness.

It has become increasingly important for researchers to study the impact of exogenous variables on the performance of project management. Trends in business have brought substantial changes to the way projects are managed. For example, increased globalization has resulted in the need to do project management across national boundaries and cultures (Cleland, 1994; Pells, 1999), and the advent of distributed organizations has brought the complexity of scattered project teams (Bourgault, et al., 2002). The impact of organizational structure, in particular the matrix organization, on successful project management has also troubled researchers and organizational designers for many years (Larson \& Gobeli, 1989; Ford \& Randolph, 1992). More recently, numerous studies linking corporate culture to organizational performance have provoked project management authors to speculate about the impact of corporate culture on project management performance
(Brown, 1999a; Brown, 1999b; Gareis, 2000; Gray, 1999). To date project management researchers could not find an objective yardstick to measure the effectiveness of project management as a dependent variable against the influence of such external influences.

The purpose of this paper is therefore to explore and conceptually define a construct of project management effectiveness based on a sound theoretical foundation. The emphasis of this construct is to be wider than the traditional focus on a single project as unit of analysis, and the achievement of the project management objectives of time, cost and performance as the primary criteria. It must address the organization's project management capability as the unit of analysis, and pay attention to issues of sustainability and predictability of future success. A further requirement is that it must facilitate large sample research, thus incorporating variables that are common to and measurable across a wide spectrum of organizations involved in project management, as well as across a wide variety of projects and project types.

It is hoped that this study will spark further theoretical and empirical research that will eventually lead to a coherent set of knowledge on this topic and the development of reliable instruments for measuring the project management effectiveness of organizations in a variety of research projects.

\section{Background}

\section{Changes in project management}

The foundations of project management were largely laid by the need to manage large projects. A large portion of the extant body of knowledge originated from the mega-project industries such as construction, defence and aerospace. 
Practitioners and researchers in the field have been mostly concerned with the issues regarding success and failure of such large projects, resulting mainly in a single project perspective of project management.

Gradually, however, several other industries have adopted project management in response to changing pressures in the marketplace. Businesses have not only been forced to respond to an increasing demand for newer and better products, but have been required to do so under strict time, cost, and quality constraints. Consequently, many businesses have had to make provision for a much larger portion of non-routine work. Besides the development of new products or services, companies also had to speed up their operational processes, change product technologies, upgrade information systems, and transform the ways they interact with suppliers and customers. Few organizations could therefore escape the introduction of projects to their daily activity. This phenomenon has resulted in a much wider interest in the application of project management as a formal management methodology.

With the adoption of project management to deal with this ongoing stream of projects, the topic can no longer be studied only from within a project perspective and as a temporary endeavour. Project management is increasingly being regarded as a standard competency or function of an organization. It has become the capability to accommodate the running of multiple projects, and to cope with the complexity of sharing and prioritizing resources between projects. This shift in emphasis is addressed by a number of authors, for example, Arenius, Artto, Lahti, and Meklin (2000), Gray and Larson (2000:10), and Rad (2000:3). The use of the term project portfolio management also shows a growing recognition in the literature for studying the simultaneous management of a range of projects (see for example Rad, 2002: 3 and Turner, 1994:4).

The topic of successful project management has therefore also become more than simply the issue of how to manage a project successfully. The concept has to include the notion of multi-projects and the issues related to a consistency in project delivery. It can also not focus mainly on the project itself, but has to address the more multi-dimensional relationship between the management of projects and the organizational environment.

The project management literature recognizes this shortcoming. Authors, for instance, Cooke-Davies (2002:188), Maylor (2001:99), and Shenhar, Dvir, Levy and Maltz (2001:701) criticize the narrow perspectives of project management success research. They call for the adoption of a more balanced and multi-dimensional approach, in line with organizational effectiveness research and The Balance Scorecard ${ }^{\circledR}$ of Kaplan and Norton. Cooke-Davies (2002: 188) adds that a balanced set of metrics, dealing with both predictors and outcomes of project success, is needed to address the issue of a consistent delivery of successful projects.

\section{Project management maturity}

Besides the literature on project management success, the concept of project management maturity is closely related to the proposed construct of project management effectiveness. Several examples of maturity models exist, such as: the Capability Maturity Model (CMM) of the Software Engineering Institute (Dooley, Subra \& Anderson, 2001); the Berkeley Project Management Process Maturity Model (Kwak \& Ibbs, 2000); and Kerzner's Project Management Maturity Model (PMMM) (Kerzner, 2001). These models pay strong attention to a variety of process variables as predictors of project outcomes, and show similarities with the concept of project management effectiveness. The CMM, for instance, emphasizes consistency, repeatability, predictability and optimizing in a multi-project environment in its different levels of maturity (Dooley et al., 2001).

Due to their detailed nature, the maturity models are more suited to the audit of project management systems in specific organizations, than to large sample empirical studies across organizations. They therefore do not serve the same purpose as the proposed effectiveness construct.

\section{Success and effectiveness terminology}

In project management literature, success appears to be the term most commonly used, both in describing project success and project management success. In other fields organizational researchers make use of more terms, like effectiveness, performance, productivity, outcomes, and efficiency (Shenhav, Shrum \& Alon, 1994:753-754). However, Shenhav et al. criticize the carelessness with which researchers often chose a term without paying attention to the theoretical agreement about its meaning.

The Merriam-Webster's Collegiate Dictionary defines success as 'a degree or measure of succeeding; or a favourable or desired outcome.' The word success is thus narrow and places emphasis primarily on the end-result of an activity. The same dictionary relates the terms effect and effective to the concept of achievement, but adds the emphasis of the process as having the inherent qualities to overcome obstacles and to possess the power to produce.

Therefore, in considering project management as a capability that can consistently manage projects successfully, effectiveness is the more appropriate term. The use of effectiveness facilitates the inclusion of outcome measures as well as process variables, or success predictors, into one construct.

\section{Outline of this study}

\section{Positioning this study in the field of project management}

The effectiveness construct is associated with the process and capability of managing projects. It is not concerned with the success and effectiveness of the project once it has been delivered and put into operation. Project management effectiveness is therefore meant to assess the ability of the organization to consistently deliver projects within the set project management objectives of time, budget and client requirements. In this sense the construct is seen as a better defined concept for comparative studies between 
organizations. More details about how the domains of project success and project management success are portrayed in the literature, is addressed in the literature research part of this study.

\section{The research approach}

This study is primarily a research of extant literature. First, it delineates the domain of project management effectiveness from the broader topic of project success. Then the study anchors itself in the organizational effectiveness literature to provide a theoretical basis from which to define the conceptual framework of project management effectiveness. Lastly, the literature on project management success is studied to extract the persistent themes and viewpoints about the topic. The study considers both the criteria that are associated with measuring success in project management, and the conditions that are viewed as predicting success. A consolidated list of variables was compiled from this study and presented to a number of acknowledged project management practitioners and theorists for their input and further refinement.

\section{Delineating project management effectiveness}

Traditionally, project management success has been associated with delivering on time, within budget and meeting performance criteria (Pinto \& Slevin, 1988: 68). In acknowledging the work by DeCotiis and Dyer (1979), and Baker, Fisher and Murphy (1983), Pinto and Slevin (1988:68) proposed the inclusion of customer satisfaction as criteria for measuring successful projects. There is still general consensus amongst project management authors about the importance of these four criteria in the field of project management.

There is, however, somewhat confusion between the concepts of project success and project management success. One of the earlier distinctions between these terms came from De Wit in 1988 (cited in Cooke-Davies, 2002: 185), who defined project success as satisfying the overall goals of the project, and project management success as satisfying the objectives of time, cost and quality.

Munns and Bjeirmi (1996:86) found, based on an extensive study of the project success literature, an overlapping and confusing use of the terms project and project management. They proposed certain criteria, in line with the De Wit definitions, to distinguish between project and project management success (see Munns \& Bjeirmi, (1996:83-85):

- $\quad$ project management ends when the project is delivered to the customer, thus corresponding only to a subset of the total life of the project;

- $\quad$ project success is a long term concept and can only be measured over the life of the project deliverables; and

- $\quad$ successful project management does not necessarily lead to project success and, vice versa, weak project management does not necessarily prevent a good project to be a commercial or operational success.
Baccarini (1999:25) made a distinction by referring to project management success and product success. Product success here is used similarly to project success as defined by Munns and Bjeirmi (1996), and implies the success of the deliverable resulting from the project. Lim and Mohamed (1999:247) again made a distinction between the macro and micro perspective of project success. Their micro criteria involve the project completion parameters, whereas the macro criteria involve satisfaction with the product by all stakeholders, in particular the users. The latter thus addresses whether the project concept serve its goals. Micro criteria correspond to project management success and macro criteria to project or product success.

The use of the term project success may add to the confusion. Shenhar and Wideman (2002:1-2) criticized the use of the term project where the product delivered by the project is in fact meant. It is thus perhaps less confusing to use a term like deliverable success, to convey the meaning of long-term project success.

Cooper (1999: 115-116) drew attention to a third component in the project success chain by using the phrases doing the right projects and doing projects right. Doing projects right focuses on the process factors and the activities of the project team, hence relating to successful project management. The concept right projects addresses mostly the issues of project selection and new product strategies, and of prioritizing between projects. This adds a further dimension, namely project selection success. Doing projects right is the responsibility of the project manager, but doing the right projects primarily lies with top management.

Figure 1 illustrates these success concepts in a diagrammatic form. This diagram shows three successive phases of projects, each with distinct influences on the eventual longterm success of the project. Through the life cycle the emphasis on managing a project's success will shift from successfully applying project selection criteria, to successfully applying project management (planning and execution), and lastly, to successfully operationalizing and commercializing the project deliverables.

This distinction is important for this study as the construct of project management effectiveness is delineated to include primarily the activities of project planning and execution and the assessment of how the project management objectives have been complied with. This corresponds to the middle phase in the diagram.

\section{The study of organizational effectiveness}

\section{Introduction}

Project management as a formally structured arrangement to achieve a specific set of objectives, complies with the following definition of organization by Schein (as cited in Lawler, Nadler \& Cammann, 1980: 2): 


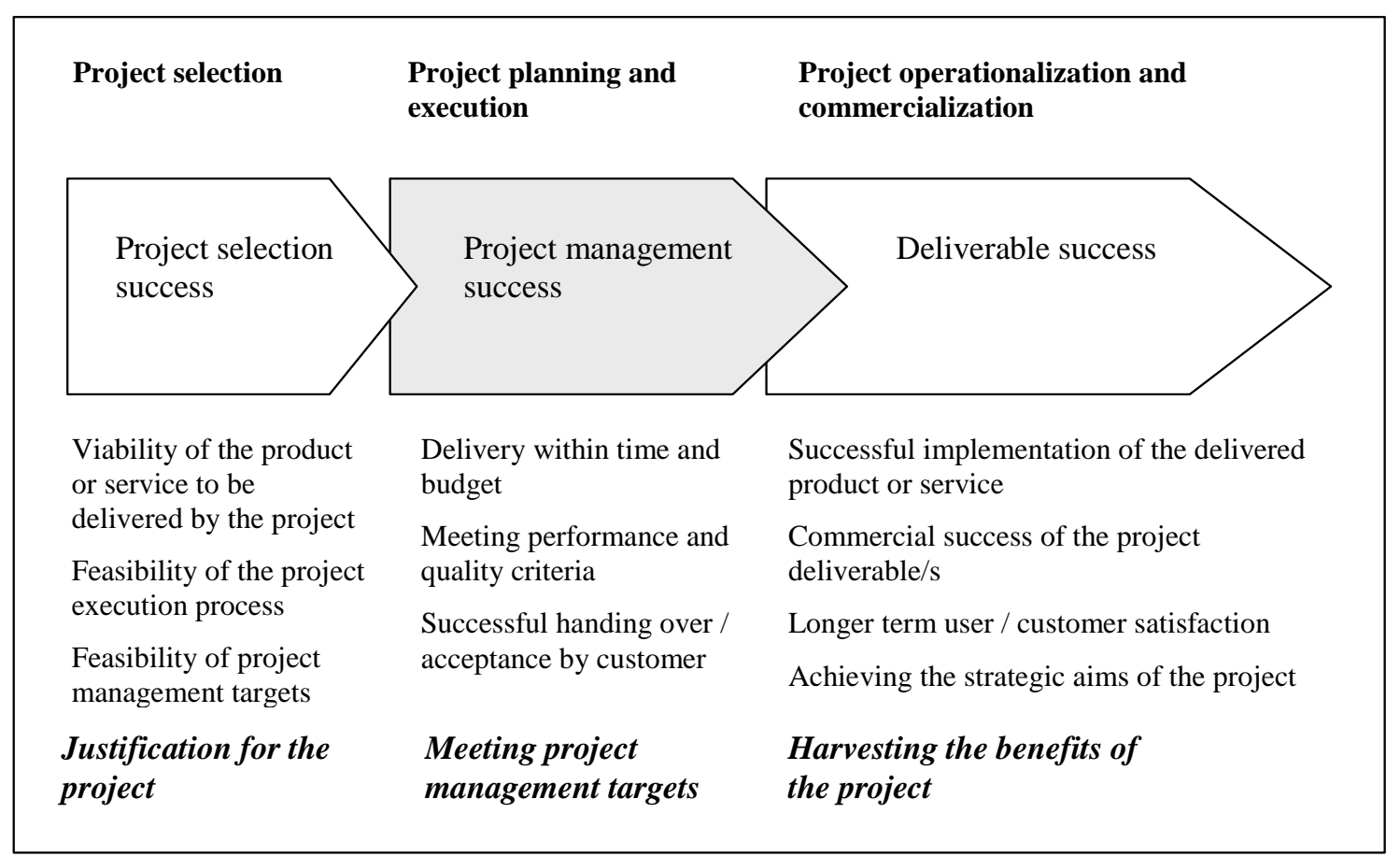

Figure 1: The domains of project success over its life cycle

The rational coordination of the activities of a number of people for the achievement of some common explicit purpose or goal through division of labor and function and through a hierarchy of authority and responsibility.

The 'open social systems' view of organizations by Katz and Kahn (as cited in Lawler, Nadler \& Cammann, 1980:2) has influenced many of the conceptual models found in the organizational effectiveness literature. This thinking emphasizes the organization in its co-existence and interaction with its environment. In line with this view, project management can be conceived as existing within a bigger organization, similar to the organization within its environment. In particular, attention is directed to the interactive and interdependent relationship between project management and the parent organization.

Open systems thinking and other prominent themes found in the organizational effectiveness body of knowledge reveal conceptual lenses that could add new perspectives to the published work on project management success. For instance, in the single project paradigm goals have dominated project management studies as the primary success criteria. Yet, goal approaches have come under severe criticism in organizational effectiveness studies. The question is whether goal approaches do not face similar shortcomings where project management is a subset of organizational activity, and where multiple projects and routine functions compete for the same resources. Denison (1990:36) comments that relying only on goal models can run into problems when goals are incompatible and conflicting.

This section therefore closely investigates the development of organizational effectiveness thinking and its relevance to a construct of project management effectiveness.

\section{Main debates and controversies}

The history of organizational effectiveness studies has been troubled by controversy, and consensus in the meaning of organizational effectiveness has remained evasive. Cameron and Whetten (1983:1) concluded that many years of work in this field had not brought researchers closer to any agreed construct of organizational effectiveness. This view was reaffirmed by Shenhav et al. (1994:771) after having conducted a comprehensive study of effectiveness literature in leading journals.

Basic differences in how scholars theorize about organizations led to different approaches to the understanding of organizational effectiveness. Gouldner (1971:12-13) distinguished between two fundamentally different views, namely the rational model and the naturalsystem model of organization. In the rational model, the organization is believed to consist of parts that can be manipulated and made to conform through rational planning and control. This viewpoint implies an emphasis on the independency of the parts of an organization. In contrast, the natural-system approach views the organization as an organism that responds with its own character flowing from the shared experiences by its members. The organization and its parts develop needs and goals separate from, and even in competition to, the formal organizational goals set by its designer. The underlying theme of natural-system views is the interdependency of organizational elements.

According to Campbell (1977:19-20) the different perceptions of organization have led to two main streams of thought in organizational effectiveness, namely the goalcentered and the natural systems approaches. Within the goal-centered viewpoints, goals are seen as rational, limited in number, and easy to define and understand. In 
comparison, the natural systems approaches focus on the complexity and dynamic nature of the organization. This perspective makes provision for an organization to adopt numerous other goals in its efforts of coping and surviving.

The complex relationships within an organization, however, were not seen to be an adequate focus of organizational effectiveness. Bennis (1971:123), based on work by Emery and Trist on open systems thinking, stressed the importance of an organization's interdependent relationship with its external environment. Bennis (1971:126-128) argued that, for an organization to be effective, it would need to manage the interaction with its environment, and it would need to have adaptive and problem-solving abilities to cope with changing environments.

\section{A critical look at goal-centered approaches}

The shortcomings of goal-dominated ways of assessing organizations, have received thorough attention from effectiveness scholars. Criticism of goals is of specific interest to the field of project management which strongly emphasizes compliance with the goals of time, cost and technical performance as its primary concern.

Although goals were perceived by many as objective assessment criteria, they were criticized for that very reason by Yuchtman and Seashore (1971:146-147) who claimed that many goals were being set subjectively in the first place. A preoccupation with goals was also questioned on the grounds of their destructive effect when they are maximally pursued at the cost of exploiting resources (Seashore \& Yuchtman, 1967:393-394). Steers (1976:51) similarly argued that organizations who were concentrating mainly on profit targets without considering the goals of employees or society, would find it hard to survive.

The multiplicity of goals in organizations has been seen to confuse assessment based mainly on goals. Yuchtman and Seashore (1971:152) stressed the difficulty in finding a rational way of identifying the variety of organizational goals. Scott (1977:64-67) distinguished between the different levels of goals in an organization, and pointed out that, in the non-rational character of organizations, there may often be discrepancies between levels. Hannan and Freeman (1977:111-113) distinguished between public goals and private or operative goals. Whereas public goals are set strategically and serve to legitimize an organization's role in society, operative goals are set at the functional level and may, due to the influence of powerful coalitions, attract nuances that deviate from the public goals. Further concerns were raised by Van de Ven and Ferry (1980:34-35) who emphasized the existence of different types of goals and the added complexity of different stakeholders having different expectations from the organization. They noticeably remarked: 'Obviously, organizations do not have goals; instead, people have goals for an organization' (Van de Ven \& Ferry, 1980: 34).

\section{Alternatives to goals}

Etzioni (1971:33-36) emphasized the importance of a 'social unit' to dedicate some of its resources toward maintaining the system. In his view the assessment of an organization should balance goal model and system model approaches to address both the needs for achieving goals, and for applying resources to serve organizational needs. This view is also reflected by Georgopoulos and Tannenbaum (1971:179-180) in their means and ends perspective to effectiveness. In specific they stressed the importance of preserving organization means by not overloading organizational relationships. Along similar lines, Steers (1976:57) proposed a process model of effectiveness that could address the assessment of key processes, but could also consider the optimization of goals within a defined set of constraints (as opposed to their mere maximization). Steers (1976:61) further recommended the evaluation of effective behaviour as part of the assessment of effectiveness.

Hannan and Freeman, in their population ecology model, (see Denison, 1990:37; Meyer \& Gupta, 1994:313) believed that the environment and its demand patterns were the key predictors of success - more so than internal conduct in the organization.

\section{Multi-dimensional perspectives}

The problematic nature of goal-oriented evaluation, however, has not ruled out the importance of goals in organizational assessment. Mohr (1983:232) questioned the use of goal-free approaches since the need to validate other criteria would inevitably call for the use of some goals. Mohr (1983:233) also reported that past non-goal ways of evaluating effectiveness, had failed to prove their adequacy in empirical studies. Hannan and Freeman (1977:111), although sharing a critical view of goals, did not support the exclusion of goals from effectiveness studies. In their view the existence of goals is what distinguishes formal organizations from informal organizations or social groupings (e.g. families and communities).

Researchers realized that organizational effectiveness could not be a simple concept taking only a limited view of organizational activity. Kirchhoff (1977:347-348), for example, criticized the past tendency to view effectiveness too narrowly, and maintained that effectiveness is multidimensional and a balanced achievement of a variety of goals. Similar criticism came from Connolly, Conlon and Deutch (1980:212), and Pfeffer and Salancik (1978:32-33) who drew attention to the complication of different interest bodies, each with their own expectations of effectiveness from a particular organization.

The awareness of different stakeholders and their influence on the organization formed the basis for the multipleconstituency approach of Connolly et al. (1980:212). A constituency is seen to include individuals or groups not necessarily directly involved with the organization, but who are sufficiently close to form opinions and to exert influence on its activities (Connolly et al., 1980:213). Seashore (1983: 55) used the term constituents as persons standing in an interdependent relationship with the organization (even members of the organization), but acting on behalf of their own or other external interests.

In a further elaboration of the multiple constituency 
approach, Zammuto (1984: 608), based on previous work by Hrebiniak, and Pfeffer and Salancik, suggested to assess the effective organization in terms of satisfying the preferences of the most powerful constituencies. Along these lines, Altschuld and Zheng (1995:6) cited further variants of the constituency approach, namely the strategic constituency models developed by Boseman and Daft respectively. Altschuld and Zheng (1995:7) also drew attention to the similarities between the constituency approaches and opensystems thinking with its emphasis on adapting to the environment.

Quinn and Rohrbaugh (1983:365-370) developed the competing values framework by testing the perceptions of experts on seventeen indices of effectiveness commonly used in previous research. They found that these clustered into a three dimensional framework of opposing values, namely flexibility versus control, external versus internal and means versus ends. This approach forms a basis for extracting preferences or values from leading constituents about how a particular organization should be run effectively.

The competing values model relates to many of the influential thinking patterns of effectiveness researchers. Quinn and Rohrbaugh (1983:369) explained how the four quadrants, formed by the two-dimensional flexibilitystability and internal-external plane, show an association with other models:

- by combining external with control - rational goal model;

- $\quad$ by combining external with flexibility - open systems model;

- by combining internal with flexibility - human relations model; and

- $\quad$ by combining internal with control - internal process model.

\section{Concluding viewpoints}

From a plethora of effectiveness studies, no one concise model of effectiveness has emerged, or seems likely to emerge. Cameron (1986:541), in reviewing a history of different models and controversies, came to the conclusion that no one best approach or set of indicators exists. He argued that different approaches may best serve different research circumstances and regarded different models as complementing rather than as replacing each other. Some of the leading effectiveness models and the circumstances that would guide the selection of a specific model, as taken from Cameron (1986:542), are:

- $\quad$ where there are clear and measurable goals, use a goal $\underline{\text { model; }}$

- where there is a clear connection between input and performance, use a system resource model;

- where there is a clear relationship between organizational processes and performance, use an internal process model;

- where constituencies have a strong influence on the focal organization, use a strategic constituencies $\underline{\text { model; }}$ and

- where the organization is unclear about its own or constituency preferences of effectiveness, use the competing values model.

The competing values perspective makes provision for different models of effectiveness to be used at the same time, and suggests that different stakeholders may emphasize different criteria of judging the same organization. Cameron (1986:549-551) maintains the opinion that placing an absolute emphasis on one set of effectiveness criteria could be dysfunctional. He cited previous studies that had used the competing values model to bring home the point that opposing, and even contradictory preferences, co-exist in organizations and contribute to effectiveness.

The Balanced Scorecard ${ }^{\circledR}$ developed by Kaplan and Norton proposed such a balanced perspective to measuring organizational performance. The model (Kaplan \& Norton, 1996:54) contemplates to assess performance in four areas of organizational activity, namely:

- $\quad$ financial results;

- $\quad$ scoring on customer-related issues;

- $\quad$ the measure of excellence of key business processes; and

- $\quad$ the ability to learn and grow.

Different effectiveness models, for example goal, constituency, internal process, and resource approaches, can be recognized within the approach of Kaplan and Norton.

What is strongly advocated is a thorough understanding of the context within which a specific effectiveness problem is researched. Cameron (1986:544) emphasize the importance of having an appropriate theoretical or conceptual picture of the context to be studied before effectiveness criteria are chosen. Campbell (1977:18-19) maintains that the effectiveness construct only has meaning when it articulates a clear theory or model of how its variables should interrelate.

\section{Summary}

The field of organizational effectiveness has clearly progressed toward a multi-dimensional perspective of effectiveness. The study revealed a number of important principles to consider when developing an effectiveness model, namely:

- the existence of different levels of goals which may include short-term operational goals as well as higher order and longer term goals; 
- the contribution of intermediate process and resource factors;

- the open systems nature of an organization and sublevels of an organization;

- the influence of constituencies and their different expectations of organizational goals; and

- the importance of a proper theoretical conceptualization of the context to be studied.

The question is how these principles relate to project management effectiveness. Firstly, project management strongly concentrates on the achievement of specific project objectives. Secondly, project management is adopted by organizations to bring them longer term strategic benefits. Thirdly, it is highly dependent on systematic processes and a reliable resource base. Fourthly, it runs in an interdependent relationship with the rest of the organization. Lastly, project management needs to address constituency considerations, such as the requirements of the customer, and the concerns and expectations of the organization's management. The key issues of project management, therefore, show important similarities with the issues that have influenced organizational effectiveness research.

\section{The study of literature on successful project management}

\section{Introduction}

The research of the project management success literature included empirical studies, literature reviews, anecdotal accounts, expert viewpoints, and textbooks. Because of the vast scope of literature that deals in some way with success, this research cannot claim that it reports exhaustively on all success related literature in project management. It does assert, however, that it has gained a reasonably complete picture of how success is viewed by leading authors. The study therefore attained a sufficient level of convergence of success concepts.

\section{Research criteria}

In order to evaluate different issues for their relevance to this study, certain criteria had been set, namely:

a) First, this study is intended to be valid for a large population of organizations, not a specific industry. Thus, items being too industry specific were excluded or were adapted to be more generically applicable.

b) Items related to project deliverable success (the longer term results or commercial success of projects) were excluded. Many sources blend or confuse this with project management success.

c) The topic of how project management strategically benefits or adds value to the organization also had to be taken into account. The multi-dimensional perspective emphasized by project management effectiveness requires a consideration of the goals different stakeholders may have of project management.

\section{Deriving the domain of the construct}

A list of about 230 statements concerning project success, project management success, and organizational expectations of project management, was extracted from the literature. This list was subjected to the above criteria and was, also by combining obviously similar statements, reduced to a more concise list of items.

The items were then categorized under headings which were considered to appropriately describe sets of related items. At this point these categories were chosen to facilitate better understanding of the complete list of items by putting them under logical headings. This process resulted in a list of 78 items grouped into 13 categories. This list, and how each item is supported by the literature, is shown in Appendix A.

\section{Domain evaluation}

A list of 29 individuals that were judged to have sufficient experience and exposure to project management was drawn up. This list included academics, practitioners and consultants, and covered a wide range of industry types, both South African and internationally.

The list of variables was drawn up in the form of a questionnaire in Microsoft Excel. This was e-mailed to each person with a covering message explaining the purpose and definition of the construct, and inviting their response. Each item had to be judged whether it belongs to the concept of project management effectiveness or not. Three options were provided, namely: Include; Exclude; or Unsure. It was also stated that they were not to judge items as necessarily belonging to the heading, but only to the overall concept of project management effectiveness. Under each heading people were asked to add any other items they would consider necessary to define the concept.

A total of 17 completed responses were received. This gave a response rate of $59 \%$ which was considered acceptable. The representativeness of responses met expectations, including two university professors in project management, three consultant/trainers in project management, and twelve project management practitioners. The respondents represented a reasonable spectrum of industry types, including information technology, construction, defence, insurance, banking, retailing and local government. Three of the responses were from outside South Africa, respectively from Australia, Germany, and Hong Kong.

Responses were evaluated in the following way. Only definite (Include or Exclude) responses were counted for each item. The Unsure response was discarded. For each item the percentage Include response was then calculated as the number of Include responses divided by the sum of Include and Exclude responses. For example, if there were 12 Includes, 2 Excludes and 3 Unsures (a total of 17 responses), the percentage Include response would be $12 / 14=85.7 \%$ 
The list was sorted in descending order per category. The Include response ranges from $100 \%$ to $62.5 \%$. A total of 11 items fell below $80 \%$. A copy of this list, indicating the responses and scoring, is included as Appendix B. All items scoring below $80 \%$ are shaded.

A total of 37 items were added by respondents. Many of these were comments rather than new variables, but they reflected the seriousness with which the respondents approached the exercise. A number of areas which could be strengthened explicitly emerged from these contributions, namely:

- $\quad$ project communication, and specifically the use of formal communications planning, status reports and change management as part of communications planning;

- $\quad$ access to technical competence, internal and external to the organization;

- the strength of subcontractors and procurement procedures; and

- the need for risk management and contingency planning.

\section{Towards a construct of project management effectiveness}

The literature study and the subsequent testing through experts, support a construct domain defined by a reasonably concise set of variables. Items belonging to all the categories were supported. An interesting observation is that many of the items that received lesser support were items linked to the larger organization's interface with project management. An explanation may lie in the fact that the expert group comprised people involved mainly in project management, and not in organizational management. Their responses may reflect a certain lack of sensitivity to the organizational concerns and expectations from project management, rather than indicate that these items do not belong to the construct. It is therefore not suggested to discard any of the items purely based on these scores, but to consider these together with other considerations, for example the measurability of an item in a practical setting, or the specific focus of a study. Most of these items have ample literature support.

A lesson can be learned from this observation. The composition of expert panels for similar project management studies should also include senior managers from organizations that are actively applying project management. These managers should, however, function on levels above project management.

A remaining question is the factor structure of the construct. The current project management literature reveals very little to confirm, with a sufficient level of confidence, a set of dimensions underlying the list of variables. Yet, closer inspection of the variables and the respective categories, suggest that there could be four main groups of dimensions, namely:

- dimensions related to the organizational input to project management;

- dimensions related to how the project management processes are executed;

- dimensions related to how project management objectives are met; and

- dimensions related to how the rest of the organization benefits from, and is impacted upon, by project management in the longer term.

Against this framework, the list of items and their headings have been regrouped into a proposed framework of eleven dimensions, as illustrated in Figure 2.

The construct contains many of the approaches and principles that have been laid down by the organizational effectiveness domain of study, namely:

- it departs from a narrow perspective to a multidimensional and balanced view of effectiveness;

- $\quad$ it focuses on multiple levels of goals;

- $\quad$ it strongly emphasizes process and resource factors;

- $\quad$ it emphasizes the interests of different constituencies and recognizes the open-systems nature of project management.

\section{Conclusion}

This study attempted to converge and give a theoretical definition to a number of effectiveness concepts that have developed in the field of project management over time. The multi-dimensional notion of project management effectiveness has become necessary, in particular for researchers, as project management has gained momentum, from being a project-by-project concept, to becoming an ongoing and standard organizational capacity.

The project management literature offers sufficient material to conceptualize the construct. The key concepts that could be put together from this literature study show a remarkable correspondence with the prominent models from the organizational effectiveness literature. An expert panel gave sufficient backing to a construct domain, defined by a list of variables extracted from the literature, to suggest that there may be empirical support for such a concept.

This study, it is hoped, will encourage scholars to expand empirical work on a more holistic and organizational perspective of project management. 


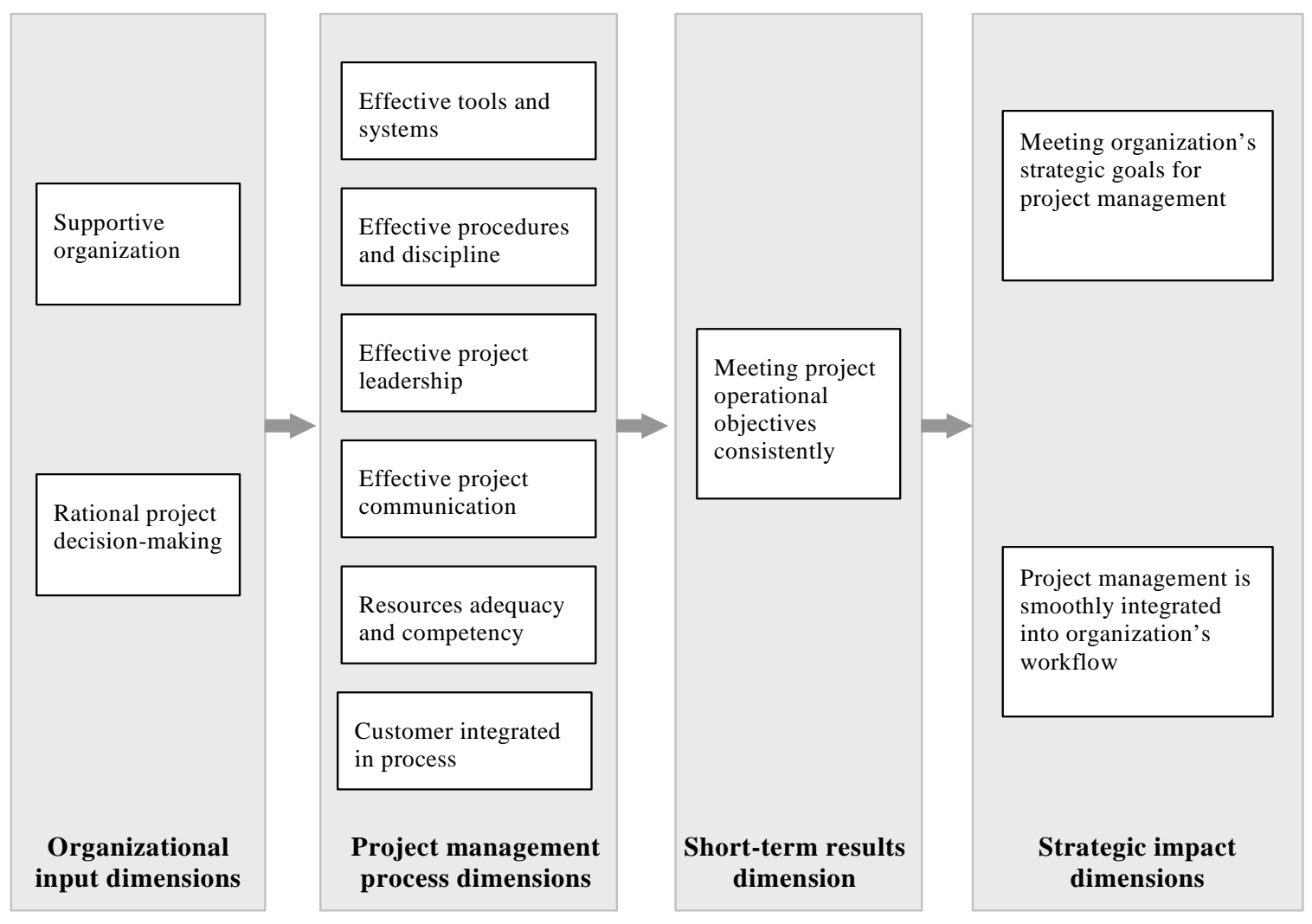

Figure 2: Proposed construct of project management effectiveness

\section{References}

Abramovici, A. 2000. 'Controlling scope creep', PM Network, January: 44-48.

Altschuld, J. W. \& Zheng, H. Y. 1995. 'Assessing the effectiveness of research organizations', Evaluation Review, 19(2):1-15. [Online full text print]. Available from EBSCOhost, Academic Search Primer Database, printed 6 February 2002.

Archibald, R.D. 1992. Managing high-technology programs and projects. 2nd Edition. New York: Wiley.

Arenius, M., Artto, K. A., Lahti, M. \& Meklin, J. 2000. 'Project companies and the multiproject paradigm: A new management approach'. In Project Management Institute. Project management research at the turn of the millennium. Proceedings of the PMI Research Conference 2000. Pennsylvania: Project Management Institute, pp.175-183.

Avots, I. 1969. 'Why does project management fail?' California Management Review, XII(1): 77-82.

Baccarini, D. 1999. 'The logical framework method for defining project success', Project Management Journal, 30(4): 25-32.

Belassi, W. \& Icmeli-Tukel, O. 1996. 'A new framework for determining critical success/failure factors in projects', International Journal of Project Management, 14(3): 141151.
Bennis, W.G. 1971. 'Towards a 'truly' scientific management: The concept of organizational health'. In Ghorpade, J (Ed.). Assessment of organizational effectiveness: Issues, analysis and readings. Pacific Palisades, CA: Goodyear, pp.116-143.

Bishop, S.K. 1999. 'Cross-functional project teams in functionally aligned organizations', Project Management Journal, September: 6-12.

Bourgault, M., Lefebvre, E., Lefebvre, L. A., Pellerin, R. \& Elie, E. 2002. 'Discussion of metrics for distributed project management: Preliminary findings'. Paper read at the 35th Hawaii Conference on System Sciences, Big Island, Hawaii, January.

Brown, C.J. 1999a. 'Can research be project managed?' South African Journal of Business Management, 30(3):7277.

Brown, C.J. 1999b. 'Towards a strategy for project management implementation', South African Journal of Business Management, 30(2): 33-38.

Cameron, K.S. \& Whetten, D.A. 1983. 'Organizational effectiveness: One model or several'. In Cameron, K.S. \& Whetten, D.A. (Eds.). Organizational effectiveness: A comparison of multiple models. Orlando: Academic Press, pp. 1-24.

Cameron, K.S. 1986. 'Effectiveness as paradox: Consensus 
and conflict in conceptions of organizational effectiveness'. Management Science, 32(5): 539-553.

Campbell, J.P. 1977. 'On the nature of organizational effectiveness'. In Goodman, S., Pennings, J. M. \& Associates (Eds.). New perspectives on organizational effectiveness. San Francisco: Jossey-Bass, pp.13-55.

Clarke, A. 1999. 'A practical use of key success factors to improve the effectiveness of project management', International Journal of Project Management, 17(3):139145 .

Cleland, D.I. 1994. 'Borderless project management'. In Cleland, D.I. \& Gareis, R. (Eds.). Global project management handbook. New York: McGraw-Hill, pp.1.31.15 .

Connolly, T., Conlon, E.J. \& Deutsch, S. J. 1980. 'Organizational effectiveness: A multiple constituency approach', Academy of Management Review, 5(2): 211-217.

Cooke-Davies, T. 2002. 'The 'real' success factors on projects', International Journal of Project Management, 20:185-190.

Cooper, R. G. \& Kleinschmidt, E. J. 1995. 'Performance typologies of new product projects', Industrial Management, 24: 439-456.

Cooper, R. G. 1998. 'Benchmarking new product performance: Results of the best practices study', European Management Journal, 16(1):1-17.

Cooper, R. G. 1999. 'From experience: The invisible success factors in product innovation', Journal of Product Innovation Management, 16:115-133.

Denison, D. R. 1990. Corporate culture and organizational effectiveness. New York: Wiley.

Dooley, K., Subra, A. \& Anderson, J. 2001. 'Maturity and its impact on new product development project performance', Research in Engineering Design, 13: 23-29.

Dvir, D., Lipovetsky, S., Shenhar, A. J. \& Tishler, A. 1998. 'In search of project classification: A non-universal approach to project success', Research Policy, 27: 915-935.

Etzioni, A. 1971. 'Two approaches to organizational analysis: A critique and a suggestion'. In Ghorpade, J. (Ed.). Assessment of organizational effectiveness: Issues, analysis and readings. Pacific Palisades, CA: Goodyear, pp.33-51.

Ford, R. C. \& Randolph, W. A. 1992. 'Cross-functional structures: A review and integration of matrix organization and project management', Journal of Management, 18(2): 267-294.

Fowler, A. \& Walsh, M. 1999. 'Conflicting perceptions of success in an information systems project', International Journal of Project Management, 17(1): 1-10.
Frame, J.D. 1994. The new project management. San Francisco: Jossey-Bass.

Frame, J.D. 1999. Project management competencies: Building key skills for individuals, teams, and organizations. San Francisco: Jossey-Bass.

Freeman, M. \& Beale, P. 1992. 'Measuring project success', Project Management Journal, XXIII(1): 8-17.

Gareis, R. 2000. 'Competences in the project-oriented organization'. In Project Management Institute. Project management research at the turn of the millennium. Proceedings of the PMI Research Conference 2000. Pennsylvania: Project Management Institute, pp.17-21.

Georgopoulos, B. S. \& Tannenbaum, A. S. 1971. 'A study of organizational effectiveness'. In Ghorpade, J. (Ed.). Assessment of organizational effectiveness: Issues, analysis and readings. Pacific Palisades, CA: Goodyear, pp.177188.

Gouldner, A.W. 1971. 'Organizational analysis'. In Ghorpade, J. (Ed.). Assessment of organizational effectiveness: Issues, analysis and readings. Pacific Palisades, CA: Goodyear, pp. 9-32.

Gray, C.F. \& Larson, E. W. 2000. Project management: The managerial process. Boston, Mass: Irwin McGraw-Hill.

Gray, R.J. 2001. 'Organisational climate and project success', International Journal of Project Management, 19: 103-109.

Hannan, M.T. \& Freeman, J. 1977. 'Obstacles to comparative studies’. In Goodman, S., Pennings, J. M. \& Associates. (Eds.). New perspectives on organizational effectiveness. San Francisco: Jossey-Bass, pp. 106-131.

Johns, T. G. 1999. 'On creating support for the project management method', International Journal of Project Management, 17(1): 47-53.

Johnson, J., Boucher, K. D, Conners, K. \& Robinson, J. 2001. 'The criteria for success', Software Magazine, February: 1-13.

Jolivet, F. \& Navarre, C. 1996. 'Large-scale projects, selforganizing and meta-rules: Towards new forms of management'. International Journal of Project Management, 14(5), 265-271.

Kaplan, R. S. \& Norton, D. P. 1996. 'Linking the balanced scorecard to strategy', California Management Review, Fall: 53-79.

Kerlinger, F. N. 1986. Foundations of behavioral research. 3rd Edition. New York: Holt, Rinehart \& Winston.

Kerzner, H. 2000. Applied project management: Best practices on implementation. New York: Wiley.

Kerzner, H. 2001. Strategic planning for project 
management using a project management maturity model. New York: Wiley.

Kerzner, H. 1998. Project management: A systems approach to planning, scheduling and controlling. 6th Edition. New York: Wiley.

Kezsbom, D. S. \& Edward, K. A. 2001. The new dynamic project management : Winning through the competitive advantage. 2nd Edition. New York: Wiley.

Kirchhoff, B.A. 1977. 'Organization effectiveness measurement and policy research', Academy of Management Review, July: 347-355.

Kwak, Y. H. \& Ibbs, C. W. 2000. 'The Berkeley project management process maturity model: Measuring the value of project management'. Proceedings of the 2000 IEEE Engineering Management Society, Albuquerque New Mexico, August.

Larson, E. W. \& Gobeli, D. H. 1989. 'Significance of project management structure on development success', IEEE Transactions on Engineering Management, 36(2): 119-125.

Lawler, E.E., Nadler, D.A. \& Cammann, C. 1980. 'Introduction'. In Lawler, E.E., Nadler, D.A. \& Cammann, C. (Eds.). Organizational assessment: Perspectives on the measurement of organizational behaviour and the quality of work life. New York: Wiley, pp.1-20.

Lechler, T. \& Gemünden, H. G. 1997. The influence structure of the success factors of project management: A conceptual framework and empirical evidence. Working paper. Karlsruhe: Institut für Angewandte Betriebswirtshaftslehre und Unternehmensführung. [Online] URL:http://www.tim.tu-berlin.de/pdf/vl_erg/AcadFin.pdf. Accessed 11 March 2002.

Lim, C. S. \& Mohamed, M. Z. 1999. 'Criteria of project success: An exploratory re-examination', International Journal of Project Management, 17(4):243-248.

Maylor, H. 2001. 'Beyond the Gantt chart: Project management moving on', European Management Journal, 19(1): 92-100.

Meredith, J. R. \& Mantel, S. J. 2000. Project management: A managerial approach. 4 th Edition. New York: Wiley.

'Merriam-Webster's collegiate dictionary.' [Online] URL:http://www.m-w.com/cgi-bin/dictionary. Accessed 8 October 2002.

Meyer, M. W. \& Gupta, V. 1994. 'The performance paradox', Research in Organizational behavior, 16:309369.

Mohr, L. B. 1983. 'The implications of effectiveness theory for managerial practice in the public sector'. In Cameron, K. S. \& Whetten, D. A. (Eds.). Organizational effectiveness: A comparison of multiple models. Orlando:
Academic Press, pp. 225-239.

Munns, A. K. \& Bjeirmi, B. F. 1996. 'The role of project management in achieving project success', International Journal of Project Management, 14(2): 81-87.

Nicholas, J. M. 1989. 'Successful project management: A force-field analysis', Journal of Systems Management, January:24-30.

Oosthuizen , Köster, M. \& De la Rey, P. 1998. Goodbye MBA: A paradigm shift towards project management. Halfway House: International Thompson.

Pells, D. 1999. 'Global tides of change: Significant recent events and trends affecting globalization of the project management profession'. In Project Management Institute. The future of project management. Pennsylvania: Project Management Institute, pp. 49-71.

Pfeffer, J. \& Salancik, G. R. 1978. The external control of organizations: A resource dependence perspective. New York: Harper \& Row.

Pinto, J. K. \& Slevin, D. P. 1988. 'Project success: Definitions and measurement techniques', Project Management Journal, XIX(1): 67-71.

Pinto, J. K. \& Mantel, S. J. 1990. 'The causes of project failure', IEEE Transactions on Engineering Management, 37(4): 269-276.

Pinto, J. K. \& Kharbanda, O. P. 1996. 'How to fail in project management (without really trying)', Business Horizons, July-August: 45-53.

Posner, B. Z. 1987. 'What it takes to be a good project manager', Project Management Journal, XVIII(1): 51-54.

Quinn, R. E. \& Rohrbaugh, J. 1983. 'A spatial model of effectiveness criteria: Towards a competing values approach to organizational analysis', Management Science, 29(3): 363-377.

Rad, F. 2000. 'Editorial', Project Management Journal, September: 3.

Rad, F. 2002. 'From the editor', Project Management Journal, September: 3.

Reichelt, K. \& Lyneis, J. 1999. 'The dynamics of project performance: Benchmarking the drivers of cost and schedule overrun', European Management Journal, 17(2):135-150.

Scott, W. R. 1977. 'The effectiveness of organizational effectiveness studies'. In Goodman: S., Pennings, J. M. \& Associates. (Eds.). New perspectives on organizational effectiveness. San Francisco: Jossey-Bass, pp. 63-95.

Seashore, S. E. \& Yuchtman, E. 1967. 'Factorial analysis of organizational performance', Administrative Science Quarterly, 12:395. 
Seashore, S. E. 1983. 'A framework for an integrated model of organizational effectiveness'. In Cameron, K. S. \& Whetten, D. A. (Eds.). Organizational effectiveness: A comparison of multiple models. Orlando: Academic Press, pp. 55-70.

Shenhar, A. J., Dvir, D., Levy, O. \& Maltz, A. C. 2001. 'Project success: A multidimensional strategic concept', Long Range Planning, 34: 699-725.

Shenhar, A. J. \& Wideman, R. M. 2002. 'Optimizing success by matching management style to project type'. Paper published on the PMForum web site, September, 2000, updated April 2002, [Online] URL:http://www.maxwideman.com/papers/success/success. pdf. Accessed 6 October 2003.

Shenhav, Y., Shrum, W. \& Alon, S. 1994. 'Goodness concepts in the study of organizations: A longitudinal survey of four leading journals', Organization Studies, 15(5): 753-776.

Slevin, D. P. \& Pinto, J. K. 1987. 'Balancing strategy and tactics in project implementation', Sloan Management Review, Fall: 33-41.

Steers, R. M. 1976. 'When is an organization effective? A process approach to understanding effectiveness', Organizational Dynamics, Autumn: 50-63.

Toney, F. \& Powers, R. 1997. Best practices of project management groups in large functional organizations. Newton Square: Project Management Institute.

Turner, J. R. 1994. 'Project management: Future developments for the short and medium term', International Journal of Project Management, 12(1): 3-4.

Van de Ven, A. H. \& Ferry, D. L. 1980. Measuring and assessing organizations. New York: Wiley.

Verner, J. M., Overmyer, S. P. \& McCain, K. W. 1999. 'In the 25 years since The Mythical Man-Month what have we learned about project management?', Information and Software Technology, 41: 1021-1026.

Vowler, J. 2000. 'The rocky road to complex project success'. Computer Weekly, December 7, 1-3, [Online] URL:http://www findarticles.com/cf_0/m0COW/2000_Dec _7/68155380/print.jhtml Accessed 8 October 2001.

Wateridge, J. 1998. 'How can IS/IT projects be measured for success?', International Journal of Project Management, 16(1): 59-53.

White, D. \& Fortune, J. 2002. 'Current practice in project management: An empirical study’, International Journal of Project Management, 20: 1-11.

Yuchtman, E. \& Seashore, S. E. 1971. 'A system resource approach to organizational effectiveness'. In Ghorpade, J.
(Ed.). Assessment of organizational effectiveness: Issues, analysis and readings. Pacific Palisades, CA: Goodyear, pp. 144-164.

Zammuto, R. F. 1984. 'A comparison of multiple constituency models of organizational effectiveness', Academy of Management Review, 9(4): 606-616. 


\section{APPENDIX A}

\section{Project management effectiveness - items from the literature.}

\section{Successful project management outcomes}

This category specifies the extent to which the standard operational project objectives are met on a consistent basis.

\begin{tabular}{|c|c|c|}
\hline No & Effectiveness factor or criterion & Citations \\
\hline 1 & Projects consistently meet their cost targets & \multirow{4}{*}{$\begin{array}{l}\text { Archibald (1992: 17); Frame (1999: 11); Freeman \& Beale } \\
\text { (1992: 10); Pinto \& Slevin (1988: 68); Wateridge (1998: } \\
\text { 59) }\end{array}$} \\
\hline 2 & Projects consistently meet time targets & \\
\hline 3 & $\begin{array}{l}\text { Projects consistently meet technical performance } \\
\text { specifications }\end{array}$ & \\
\hline 4 & $\begin{array}{l}\text { Projects consistently meet the required quality } \\
\text { standards }\end{array}$ & \\
\hline 5 & $\begin{array}{l}\text { Clients or end-users are consistently satisfied with what } \\
\text { our projects deliver }\end{array}$ & $\begin{array}{l}\text { Frame (1994: 5, 9, 11); Freeman \& Beale (1992: 10); } \\
\text { Kerzner (2000: 31); Pinto \& Mantel (1990: 270); Pinto \& } \\
\text { Slevin (1988: 68); Wateridge (1998: 61) }\end{array}$ \\
\hline 6 & Clients generally talk positively about our project work & Kerzner (2000: 31) \\
\hline
\end{tabular}

\section{Meeting the organizational goals for project management}

This category assesses the degree to which organizational expectations of project management are met, besides meeting the direct project management objectives. In other words, it addresses how well project management delivers the intended strategic benefits to the organization.

\begin{tabular}{c|l|l}
\hline No & \multicolumn{1}{|c|}{ Effectiveness factor or criterion } & \multicolumn{1}{c}{ Citations } \\
\hline 1 & $\begin{array}{l}\text { Project management improves the ability of the } \\
\text { organization to utilise its human resources and } \\
\text { specialists }\end{array}$ & $\begin{array}{l}\text { Frame (1999: 15); Kerzner (2000: 158); Kezsbom \& } \\
\text { Edwards (2001, p 35) }\end{array}$ \\
\hline 2 & $\begin{array}{l}\text { Project management allows the organization to better } \\
\text { respond to client demands }\end{array}$ & $\begin{array}{l}\text { Gray \& Larson (2000: 10); Kerzner (1998: 37); Kezsbom } \\
\text { \& Edwards (2001, p 35); Oosthuizen, Köster \& De La Rey } \\
\text { (1998: 29) }\end{array}$ \\
\hline 3 & $\begin{array}{l}\text { Project management allows the organization to better } \\
\text { manage legitimate stakeholder demands }\end{array}$ & $\begin{array}{l}\text { Oosthuizen, Köster \& De La Rey (1998: 29); Jolivet \& } \\
\text { Navarre (1996: 265) }\end{array}$ \\
\hline 5 & $\begin{array}{l}\text { Project management creates a faster work flow } \\
\text { (horizontal) in delivering new products }\end{array}$ & $\begin{array}{l}\text { Bishop (1999: 6); Gray \& Larson (2000: 7); Kerzner } \\
\text { (1998: 37); Meredith \& Mantel (2000: 140); Toney \& } \\
\text { Powers (1997: 7) }\end{array}$ \\
\hline 6 & $\begin{array}{l}\text { Project management succeeds to free top management } \\
\text { from coordinating major new projects or developments }\end{array}$ & $\begin{array}{l}\text { Kerzner (1998: 37); Jolivet \& Navarre (1996: 265); } \\
\text { Meredith \& Mantel (2000: 140) }\end{array}$ \\
\hline
\end{tabular}




\section{Project goal clarity and alignment}

This category judges the extent to which project goals are clearly defined upfront, are articulated to project participants, and generally attain the commitment of participants.

\begin{tabular}{|c|c|c|}
\hline No & Effectiveness factor or criterion & Citations \\
\hline 1 & Project goals are clearly defined at start-up & \multirow{2}{*}{$\begin{array}{l}\text { Baker, Murphy \& Fisher (1983) in Belassi \& Icmeli-Tukel } \\
\text { (1996: 143); Gray \& Larson (2000: 17); Johnson et al. } \\
\text { (2001: 2); Pinto \& Mantel (1990: 270); Posner (1987: 51); } \\
\text { White \& Fortune (2002: 6) }\end{array}$} \\
\hline 2 & Project goals are made clear to all participants & \\
\hline 3 & $\begin{array}{l}\text { Project participants are committed to the achievement } \\
\text { of project goals }\end{array}$ & \multirow[t]{2}{*}{$\begin{array}{l}\text { Baker, Murphy \& Fisher (1983) in Belassi \& Icmeli-Tukel } \\
\text { (1996: 143); Gray \& Larson (2000: 17) }\end{array}$} \\
\hline 4 & Project team members take ownership of project goals & \\
\hline 5 & $\begin{array}{l}\text { Team members actively participate in decision-making } \\
\text { regarding the achievement of project goals }\end{array}$ & Lechler \& Gemünden (1997: 5) \\
\hline
\end{tabular}

\section{A rational and merit approach to projects and project management}

This category assesses the degree to which project targets are based on proper analytical methods and homework, and project goals are realistically set. The project decision rationale should be the pursuit of organizational interests and not the pursuit of personal interests or inter-departmental power concerns.

\begin{tabular}{|c|c|c|}
\hline No & Effectiveness factor or criterion & Citations \\
\hline 1 & $\begin{array}{l}\text { There is an emphasis on up-front project homework } \\
\text { and feasibility studies }\end{array}$ & $\begin{array}{l}\text { Cleland \& King (1983) in Belassi \& Icmeli-Tukel (1996: } \\
\text { 143); Cooper \& Kleinschmidt (1995: 454); Cooper (1999: } \\
\text { 119); Pinto \& Kharbanda (1996: 46) }\end{array}$ \\
\hline 2 & $\begin{array}{l}\text { Project estimates and planning are as far as possible } \\
\text { done on factual and reliable information }\end{array}$ & $\begin{array}{l}\text { Posner (1987: 51); Gray \& Larson (2000: 17); White \& } \\
\text { Fortune (2002: 6); Belassi \& Icmeli-Tukel (1996: 145) }\end{array}$ \\
\hline 3 & $\begin{array}{l}\text { Care is taken to ensure that there is market or end-user } \\
\text { support for the proposed project }\end{array}$ & $\begin{array}{l}\text { Pinto \& Slevin (1989) in Belassi \& Icmeli-Tukel (1996: } \\
\text { 143); Slevin \& Pinto (1987: 34) }\end{array}$ \\
\hline 4 & $\begin{array}{l}\text { Personal interest and political considerations do not } \\
\text { dictate project decisions }\end{array}$ & Pinto \& Kharbanda (1996: 46) \\
\hline 5 & $\begin{array}{l}\text { Projects are not subject to unrealistic deadlines and } \\
\text { targets }\end{array}$ & Gray \& Larson (2000: 17); White \& Fortune (2002: 6) \\
\hline 6 & $\begin{array}{l}\text { Projects are continually reviewed to re-evaluate their } \\
\text { viability and potential success }\end{array}$ & \multirow{3}{*}{$\begin{array}{l}\text { Cleland \& King (1983) in Belassi \& Icmeli-Tukel (1996: } \\
\text { 143); Cooper \& Kleinschmidt (1995: 454); Cooper (1999: } \\
\text { 119); Pinto \& Kharbanda (1996: 46); Vowler (2000: 3) }\end{array}$} \\
\hline 7 & $\begin{array}{l}\text { Projects are rather terminated early or adapted when } \\
\text { they are not meeting initial expectations }\end{array}$ & \\
\hline 8 & $\begin{array}{l}\text { It is customary to have formal reviews to learn from } \\
\text { project failures and/or successes }\end{array}$ & \\
\hline 9 & Project priorities are not changed too frequently & Cooper (1999: 119) \\
\hline
\end{tabular}




\section{Appropriate project management methodology}

This assesses the degree to which the organization follows a standardized and formal methodology of project management with appropriate supportive systems, processes and procedures.

\begin{tabular}{|c|c|c|}
\hline No & Effectiveness factor or criterion & Citations \\
\hline 1 & $\begin{array}{l}\text { The organization has a standardized and effective } \\
\text { system for managing projects }\end{array}$ & \multirow{2}{*}{$\begin{array}{l}\text { Avots (1969: 80); Cooper (1998: 3); Johnson et al. (2001: } \\
\text { 3); Kerzner (2001: 42-43); Lechler \& Gemünden (1997: } \\
\text { 5); Martin (1976) in Belassi \& Icmeli-Tukel (1996: 143); } \\
\text { Nicholas (1989: 29) }\end{array}$} \\
\hline 2 & $\begin{array}{l}\text { Project participants generally understand the project } \\
\text { management procedures applied in the organization }\end{array}$ & \\
\hline 3 & $\begin{array}{l}\text { The organization has the ability to estimate and plan its } \\
\text { projects with reasonable accuracy }\end{array}$ & $\begin{array}{l}\text { Clarke (1999: 140); Baker, Murphy \& Fisher (1983) in } \\
\text { Belassi \& Icmeli-Tukel (1996: 143); Gray \& Larson (2000: } \\
\text { 17); Lechler \& Gemünden (1997: 5); Nicholas (1989: 29); } \\
\text { Posner (1987: 51) }\end{array}$ \\
\hline 4 & $\begin{array}{l}\text { The project management process facilitate the } \\
\text { implementation of projects with minimum start-up } \\
\text { problems }\end{array}$ & $\begin{array}{l}\text { Baker, Murphy \& Fisher (1983) in Belassi \& Icmeli-Tukel } \\
\text { (1996: 143); Morris \& Hough (1987) in Belassi \& Icmeli- } \\
\text { Tukel (1996: 143) }\end{array}$ \\
\hline 5 & $\begin{array}{l}\text { Project management process involves strong } \\
\text { monitoring and control over activities on an ongoing } \\
\text { basis }\end{array}$ & $\begin{array}{l}\text { Dvir, et al. (1998: 932); Lechler \& Gemünden (1997: 5); } \\
\text { Pinto \& Mantel (1990: 270); Wateridge (1998: 60); White } \\
\text { \& Fortune (2002: 6); \& Baker, Murphy \& Fisher (1983), } \\
\text { Lock (1984), \& Sayles \& Chandler (1971), all in Belassi \& } \\
\text { Icmeli-Tukel (1996: 143) }\end{array}$ \\
\hline 6 & There is an adequate focus on managing project risks & $\begin{array}{l}\text { Cooke-Davies (2002: 186); Pinto \& Kharbanda (1996: 46); } \\
\text { Vowler (2000: 3) }\end{array}$ \\
\hline 7 & $\begin{array}{l}\text { Project scope is comprehensively and adequately } \\
\text { defined }\end{array}$ & $\begin{array}{l}\text { Clarke (1999: 140); Cooper \& Kleinschmidt (1995: 454); } \\
\text { Cooper (1999: 119); Gray \& Larson (2000: 17); Nicholas } \\
\text { (1989: 29) }\end{array}$ \\
\hline 8 & $\begin{array}{l}\text { The organization has appropriate tools and systems to } \\
\text { support the project management process }\end{array}$ & $\begin{array}{l}\text { Avots (1969: 80); Lechler \& Gemünden (1997: 5); Martin } \\
\text { (1976) in Belassi \& Icmeli-Tukel (1996: 143); Slevin \& } \\
\text { Pinto (1987: 34) }\end{array}$ \\
\hline 9 & $\begin{array}{l}\text { Project participants generally believe in the project } \\
\text { management procedures applied in the organization }\end{array}$ & Johns (1999: 53); Nicholas (1989: 29) \\
\hline 10 & Project scope is changed only in a controlled way & $\begin{array}{l}\text { Abramovici (2000: 48); Avots (1969: 79); Cooke-Davies } \\
\text { (2002: 186); Kerzner (1992) in Baccarini (1999: 28); } \\
\text { Nicholas (1989: 29) }\end{array}$ \\
\hline
\end{tabular}




\section{Effective project organization and authority structure}

This category evaluates the extent to which there are effective ways of organizing project teams, assigning project responsibilities, and delegating authority to make decisions.

\begin{tabular}{|c|c|c|}
\hline No & Effectiveness factor or criterion & Citations \\
\hline 1 & $\begin{array}{l}\text { Project managers are given the necessary authority to } \\
\text { execute their responsibilities }\end{array}$ & $\begin{array}{l}\text { Cooke-Davies (2002: 186); Cooper \& Kleinschmidt (1995: } \\
\text { 453); Lechler \& Gemünden (1997: 5); Vowler (2000: 3) }\end{array}$ \\
\hline 2 & $\begin{array}{l}\text { Project team members understand their project } \\
\text { responsibilities }\end{array}$ & $\begin{array}{l}\text { Cooke-Davies (2002: 186); Martin (1976) in Belassi \& } \\
\text { Icmeli-Tukel (1996: 143) }\end{array}$ \\
\hline 3 & There are clearly laid down decision-making principles & Vowler (2000: 3) \\
\hline 4 & Decision-making is smooth and efficient & Vowler (2000: 3) \\
\hline 5 & $\begin{array}{l}\text { Project teams are generally effectively structured and } \\
\text { mobilized }\end{array}$ & Avots (1969: 78); Cooper \& Kleinschmidt (1995: 453) \\
\hline 6 & $\begin{array}{l}\text { Project managers are held accountable for meeting their } \\
\text { responsibilities }\end{array}$ & $\begin{array}{l}\text { Cooke-Davies (2002: 186); Cooper \& Kleinschmidt (1995: } \\
\text { 453); Martin (1976) in Belassi \& Icmeli-Tukel (1996: } 143 \text { ) }\end{array}$ \\
\hline
\end{tabular}

\section{Access to the resources needed to execute projects}

This measures the degree to which project managers can rely on a strong enough resource base and can adequately access and manage the assigned resources.

\begin{tabular}{|c|c|c|}
\hline No & Effectiveness factor or criterion & Citations \\
\hline 1 & $\begin{array}{l}\text { Project managers are adequately empowered to access } \\
\text { the required resources for their projects }\end{array}$ & Lechler \& Gemünden (1997: 5) \\
\hline 2 & $\begin{array}{l}\text { The organization is committed to providing the agreed } \\
\text { upon resources }\end{array}$ & \multirow{2}{*}{$\begin{array}{l}\text { Belassi \& Icmeli-Tukel (1996: 145); Cooper (1998: 11); } \\
\text { Posner (1987: 51); White \& Fortune (2002: 6); Baker, } \\
\text { Murphy \& Fisher (1983) in Belassi \& Icmeli-Tukel (1996: } \\
\text { 143) }\end{array}$} \\
\hline 3 & $\begin{array}{l}\text { Project managers can normally rely on the work output } \\
\text { of organizational resources }\end{array}$ & \\
\hline 4 & $\begin{array}{l}\text { The organization makes adequate provision for project } \\
\text { funding }\end{array}$ & $\begin{array}{l}\text { Baker, Murphy \& Fisher (1983) in Belassi \& Icmeli-Tukel } \\
\text { (1996: 143); Cleland \& King (1983) in Belassi \& Icmeli- } \\
\text { Tukel (1996: 143); White \& Fortune (2002: 6) }\end{array}$ \\
\hline 5 & $\begin{array}{l}\text { The availability of resources are taken into account } \\
\text { when deciding upon projects and setting priorities }\end{array}$ & Cooper (1999: 119, 129, 133); Posner (1987: 51) \\
\hline
\end{tabular}




\section{Supportive organization}

This category evaluates to what extent top management and the entire organization understand and support the project management function, and to what extent project priorities are aligned with organizational priorities.

\begin{tabular}{|c|c|c|}
\hline No & Effectiveness factor or criterion & Citations \\
\hline 1 & $\begin{array}{l}\text { Top management has an understanding of what project } \\
\text { management entails }\end{array}$ & \multirow{2}{*}{$\begin{array}{l}\text { Avots (1969: 79); Nicholas (1989: 29); Pinto \& Mantel } \\
\text { (1990: 270); Belassi \& Icmeli-Tukel (1996: 145); Cleland } \\
\text { \& King (1983) in Belassi \& Icmeli-Tukel (1996: 143); } \\
\text { Lechler \& Gemünden (1997: 5); Cooper (1998: 13); } \\
\text { Fowler \& Walsh (1999: 8); Gray \& Larson (2000: 17); } \\
\text { Johnson et al. (2001: 2); White \& Fortune (2002: 6) }\end{array}$} \\
\hline 2 & $\begin{array}{l}\text { Top management members take active interest in } \\
\text { projects and give support when necessary }\end{array}$ & \\
\hline 3 & $\begin{array}{l}\text { Project work generally is supported by the rest of the } \\
\text { organization }\end{array}$ & $\begin{array}{l}\text { Cooper (1999: 119); Gray \& Larson (2000: 17); Johns } \\
\text { (1999: 53); Posner (1987: 51); Cleland \& King (1983), and } \\
\text { Sayles \& Chandler (1971) both in Belassi and Icmeli-Tukel } \\
\text { (1996: 143) }\end{array}$ \\
\hline 4 & $\begin{array}{l}\text { Projects are not seriously affected by conflict existing } \\
\text { between departments }\end{array}$ & Posner (1987: 51) \\
\hline 5 & $\begin{array}{l}\text { Top management ensure that project priorities are well- } \\
\text { defined and are subscribed to by the rest of the } \\
\text { organization }\end{array}$ & $\begin{array}{l}\text { Cooper (1999: 119, 129); Lock (1984) in Belassi \& Icmeli- } \\
\text { Tukel (1996: 143); Posner (1987: 51); Slevin \& Pinto } \\
\text { (1987: 34) }\end{array}$ \\
\hline 6 & $\begin{array}{l}\text { People from different departments in the organization } \\
\text { work together well in project teams }\end{array}$ & Posner (1987: 51) \\
\hline
\end{tabular}

\section{Sound communications in projects}

This measures whether there is a healthy level of communication in project teams and whether there is an emphasis on the efficient dissemination of important project related information to all participants

\begin{tabular}{|c|c|c|}
\hline No & Effectiveness factor or criterion & Citations \\
\hline 1 & $\begin{array}{l}\text { Project team members often informally discuss project } \\
\text { matters }\end{array}$ & \multirow{5}{*}{$\begin{array}{l}\text { Clarke (1999: 140); Cleland \& King (1983) in Belassi \& } \\
\text { Icmeli-Tukel (1996: 143); Fowler \& Walsh (1999: 8); } \\
\text { Lechler \& Gemünden (1997: 5); Lock (1984) in Belassi \& } \\
\text { Icmeli-Tukel (1996: 143); Nicholas (1989: 29); Pinto \& } \\
\text { Mantel (1990: 270); Posner (1987: 51); Slevin \& Pinto } \\
\text { (1987: 34); Verner, Overmyer \& McCain (1999: 1025); } \\
\text { White \& Fortune (2002: 6) }\end{array}$} \\
\hline 2 & $\begin{array}{l}\text { Team members are kept informed of project progress } \\
\text { and developments }\end{array}$ & \\
\hline 3 & Project meetings are usually informative & \\
\hline 4 & $\begin{array}{l}\text { Project information systems provide helpful and } \\
\text { accurate project information }\end{array}$ & \\
\hline 5 & The channels for reporting project problems are clear & \\
\hline
\end{tabular}




\section{Effective consultation with the client or end-user}

This category measures to what extent the project management process encourages and effectively facilitates consultation with the client or end-user on a regular or ongoing basis.

\begin{tabular}{c|l|l}
\hline No & \multicolumn{1}{|c|}{ Effectiveness factor or criterion } & \multicolumn{1}{c}{ Citations } \\
\hline 1 & $\begin{array}{l}\text { During project execution regular discussions are } \\
\text { maintained with the client or end-user }\end{array}$ & $\begin{array}{l}\text { Cooper (1999: 119); Belassi \& Icmeli-Tukel (1996: 145); } \\
\text { Dvir, et al. (1998: 932); Gray \& Larson (2000: 17); }\end{array}$ \\
\cline { 1 - 2 } 2 & $\begin{array}{l}\text { Client or end-user inputs are considered when making } \\
\text { project decisions }\end{array}$ & $\begin{array}{l}\text { Mantel (1990: 270); Slevin \& Pinto (1987: 34); Verner, } \\
\text { Overmyer \& McCain (1999: 1025) }\end{array}$ \\
\hline 3 & $\begin{array}{l}\text { There are normally good relations between project } \\
\text { teams and their clients }\end{array}$ & \\
\cline { 1 - 2 } 4 & Each project has an identified client or end-user & \\
\hline
\end{tabular}

\section{Quality of project leadership}

This category evaluates whether the organization ensures that effective project leadership is put into place for each project.

\begin{tabular}{|c|c|c|}
\hline No & Effectiveness factor or criterion & Citations \\
\hline 1 & $\begin{array}{l}\text { Care is taken to put competent project managers in } \\
\text { charge of projects }\end{array}$ & \multirow{4}{*}{$\begin{array}{l}\text { Avots (1969: 78); Belassi \& Icmeli-Tukel (1996: 145); } \\
\text { Johnson et al. (2001: 2); Lock (1984) in Belassi \& Icmeli- } \\
\text { Tukel (1996: 143); Nicholas (1989: 29); Pinto \& } \\
\text { Kharbanda (1996: 46); White \& Fortune (2002: 6); Pinto \& } \\
\text { Slevin (1989) in Belassi \& Icmeli-Tukel (1996: 143); } \\
\text { Sayles \& Chandler (1971) in Belassi \& Icmeli-Tukel (1996: } \\
\text { 143); Verner, Overmyer \& McCain (1999: 1025); Vowler } \\
\text { (2000: 3) }\end{array}$} \\
\hline 2 & $\begin{array}{l}\text { The organization has a core of experienced project } \\
\text { managers }\end{array}$ & \\
\hline 3 & $\begin{array}{l}\text { Project managers have suitable team and people } \\
\text { leadership qualities }\end{array}$ & \\
\hline 4 & $\begin{array}{l}\text { The organization takes adequate steps to appropriately } \\
\text { train project managers }\end{array}$ & \\
\hline
\end{tabular}

\section{Project human resource adequacy}

This category assesses the extent to which people assigned to projects are generally competent in their line of specialization and display a sufficient commitment to delivering quality work. This category also requires participants to be sufficiently skilled in project management and teamwork, and to have, amongst them, sufficient problem-solving abilities.

\begin{tabular}{|c|c|c|}
\hline No & Effectiveness factor or criterion & Citations \\
\hline 1 & $\begin{array}{l}\text { People participating in projects are generally competent } \\
\text { in their fields of expertise }\end{array}$ & \multirow{2}{*}{$\begin{array}{l}\text { Baker, Murphy \& Fisher (1983) in Belassi \& Icmeli-Tukel } \\
\text { (1996: 143); Dvir, et al. (1998: 931); Freeman \& Beale } \\
\text { (1992: 10); Gray \& Larson (2000: 17); Pinto \& Mantel } \\
\text { (1990: 270) }\end{array}$} \\
\hline 2 & $\begin{array}{l}\text { Project team members have adequate project } \\
\text { management related skills }\end{array}$ & \\
\hline 3 & $\begin{array}{l}\text { There are always enough project team members around } \\
\text { with innovative and problem-solving abilities }\end{array}$ & Freeman \& Beale (1992: 10) \\
\hline 4 & $\begin{array}{l}\text { There is an acceptably low level of rework in most } \\
\text { projects }\end{array}$ & Reichelt \& Lyneis (1999: 148-149) \\
\hline 5 & $\begin{array}{l}\text { Project team members have adequate teamwork } \\
\text { orientation and skills }\end{array}$ & $\begin{array}{l}\text { Cooper (1998: 13); Cooper (1999: 122); Lechler \& } \\
\text { Gemünden (1997: 5); Nicholas (1989: 29) }\end{array}$ \\
\hline 6 & $\begin{array}{l}\text { Project team members have the maturity to work } \\
\text { independently on project tasks }\end{array}$ & Dvir, et al. (1998: 931); Gray \& Larson (2000: 17) \\
\hline
\end{tabular}




\section{Consideration for stakeholders}

The last category is concerned with the extent to which project management is carried out with an "open systems" mindset. This aspect groups items which consider the interdependent relationship between project management and the rest of the organization, as well as with the environment.

\begin{tabular}{|c|c|c|}
\hline No & Effectiveness factor or criterion & Citations \\
\hline 1 & $\begin{array}{l}\text { Projects are carried out without compromising the } \\
\text { culture and values of the organization }\end{array}$ & $\begin{array}{l}\text { Freeman \& Beale (1992: 10); Kerzner (1992) in Baccarini } \\
\text { (1999: 28); Kerzner (1989) in Wateridge (1998: 60) }\end{array}$ \\
\hline 2 & $\begin{array}{l}\text { Project team members are generally satisfied with } \\
\text { participating in projects and how it contributes to their } \\
\text { career growth }\end{array}$ & Archibald (1992: 17); Freeman \& Beale (1992: 10) \\
\hline 3 & $\begin{array}{l}\text { Projects are done without disrupting the rest of the } \\
\text { organization's workflow }\end{array}$ & $\begin{array}{l}\text { Freeman \& Beale (1992: 10); Kerzner (1992) in Baccarini } \\
\text { (1999: 28); Kerzner (1989) in Wateridge (1998: 60) }\end{array}$ \\
\hline 4 & $\begin{array}{l}\text { Project management is done in harmony with the } \\
\text { functioning of line management in the organization }\end{array}$ & Kerzner (2000: 158); Wateridge (1998: 63) \\
\hline 5 & $\begin{array}{l}\text { Project management always consult people that may be } \\
\text { affected by projects (internal and external to the } \\
\text { organization) }\end{array}$ & $\begin{array}{l}\text { Morris \& Hough (1987) in Belassi \& Icmeli-Tukel (1996: } \\
\text { 143); Pinto \& Kharbanda (1996: 46); Pinto \& Slevin (1989) } \\
\text { in Belassi \& Icmeli-Tukel (1996: 143) }\end{array}$ \\
\hline 6 & $\begin{array}{l}\text { Project management activities are sensitive to the } \\
\text { dominant political sentiments in the organization }\end{array}$ & $\begin{array}{l}\text { Morris \& Hough (1987) in Belassi \& Icmeli-Tukel (1996: } \\
\text { 143) }\end{array}$ \\
\hline
\end{tabular}




\section{APPENDIX B}

Expert feedback: Items sorted in descending order by scores (per category).

\begin{tabular}{|c|c|c|c|c|c|c|}
\hline 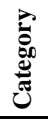 & 之 & Item description & 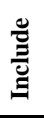 & 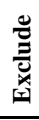 & ڤ્) & ڤัँ \\
\hline \multirow{6}{*}{ 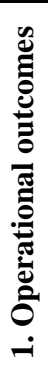 } & 1 & Projects consistently meet their cost targets & 15 & 0 & 2 & 1.00 \\
\hline & 2 & Projects consistently meet time targets & 15 & 0 & 2 & 1.00 \\
\hline & 3 & Projects consistently meet the required quality standards & 16 & 0 & 1 & 1.00 \\
\hline & 4 & Projects consistently meet their technical performance specifications & 17 & 0 & 0 & 1.00 \\
\hline & 5 & Clients or end-users are consistently satisfied with what our projects deliver & 17 & 0 & 0 & 1.00 \\
\hline & 6 & Clients generally talk positively about our project work & 11 & 2 & 4 & 0.85 \\
\hline \multirow{6}{*}{ 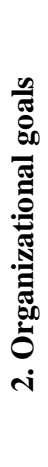 } & 7 & Project management creates a faster work flow in delivering new products & 12 & 0 & 5 & 1.00 \\
\hline & 8 & $\begin{array}{l}\text { Project management improves the ability of the organization to utilise its human } \\
\text { resources and specialists }\end{array}$ & 15 & 1 & 1 & 0.94 \\
\hline & 9 & $\begin{array}{l}\text { Project management enhances the concurrent use of multi-functional inputs in new } \\
\text { development work in the organization }\end{array}$ & 13 & 2 & 2 & 0.87 \\
\hline & 10 & Project management allows the organization to better respond to client demands & 14 & 3 & 0 & 0.82 \\
\hline & 11 & $\begin{array}{l}\text { Project management allows the organization to better manage legitimate stakeholder } \\
\text { demands }\end{array}$ & 11 & 4 & 2 & 0.73 \\
\hline & 12 & $\begin{array}{l}\text { Project management succeeds to free top management from coordinating major new } \\
\text { projects or developments }\end{array}$ & 9 & 5 & 3 & 0.64 \\
\hline \multirow{5}{*}{ 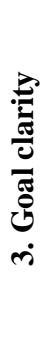 } & 13 & Project goals are clearly defined at start-up & 16 & 0 & 1 & 1.00 \\
\hline & 14 & Project goals are made clear to all participants & 16 & 0 & 1 & 1.00 \\
\hline & 15 & Project participants are committed to the achievement of project goals & 16 & 0 & 1 & 1.00 \\
\hline & 16 & Project team members take ownership of project goals & 16 & 1 & 0 & 0.94 \\
\hline & 17 & $\begin{array}{l}\text { Team members actively participate in decision-making regarding the achievement of } \\
\text { project goals }\end{array}$ & 15 & 2 & 0 & 0.88 \\
\hline \multirow{9}{*}{ 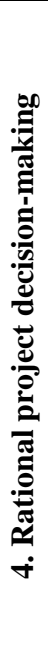 } & 18 & $\begin{array}{l}\text { Project estimates and planning are as far as possible done on factual and reliable } \\
\text { information }\end{array}$ & 16 & 0 & 1 & 1.00 \\
\hline & 19 & It is customary to have formal reviews to learn from project failures and/or successes & 16 & 0 & 1 & 1.00 \\
\hline & 20 & There is an emphasis on up-front project homework and feasibility studies & 17 & 0 & 0 & 1.00 \\
\hline & 21 & Projects are continually reviewed to re-evaluate their viability and potential success & 16 & 1 & 0 & 0.94 \\
\hline & 22 & $\begin{array}{l}\text { Care is taken to ensure that there is market or end-user support for the proposed } \\
\text { project }\end{array}$ & 13 & 2 & 2 & 0.87 \\
\hline & 23 & Projects are not subject to unrealistic deadlines and targets & 12 & 2 & 3 & 0.86 \\
\hline & 24 & Project priorities are not changed too frequently & 10 & 2 & 5 & 0.83 \\
\hline & 25 & $\begin{array}{l}\text { Projects are rather terminated early or adapted when they are not meeting initial } \\
\text { expectations }\end{array}$ & 13 & 4 & 0 & 0.76 \\
\hline & 26 & Personal interest and political considerations do not dictate project decisions & 10 & 4 & 3 & 0.71 \\
\hline
\end{tabular}

$\mathrm{N}=17$

Score $=$ Include $/$ (Include + Exclude $)$ 


\begin{tabular}{|c|c|c|c|c|c|c|}
\hline 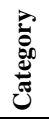 & z & Item description & 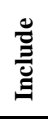 & 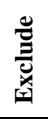 & 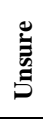 & ڤัٌ \\
\hline \multirow{10}{*}{ 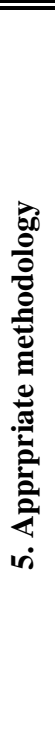 } & 27 & Project scope is comprehensively and adequately defined & 16 & 0 & 1 & $\overline{1.00}$ \\
\hline & 28 & $\begin{array}{l}\text { The organization has the ability to estimate and plan its projects with reasonable } \\
\text { accuracy }\end{array}$ & 17 & 0 & 0 & 1.00 \\
\hline & 29 & There is an adequate focus on managing project risks & 17 & 0 & 0 & 1.00 \\
\hline & 30 & Project scope is changed only in a controlled way & 17 & 0 & 0 & 1.00 \\
\hline & 31 & The organization has a standardised and effective system for managing projects & 16 & 1 & 0 & 0.94 \\
\hline & 32 & $\begin{array}{l}\text { Project participants generally understand the project management procedures } \\
\text { applied in the organization }\end{array}$ & 15 & 1 & 1 & 0.94 \\
\hline & 33 & $\begin{array}{l}\text { The organization has appropriate tools and systems to support the project } \\
\text { management process }\end{array}$ & 14 & 1 & 2 & 0.93 \\
\hline & 34 & $\begin{array}{l}\text { The project management process facilitate the implementation of projects with } \\
\text { minimum start-up problems }\end{array}$ & 12 & 1 & 4 & 0.92 \\
\hline & 35 & $\begin{array}{l}\text { Project participants generally believe in the project management procedures applied } \\
\text { in the organization }\end{array}$ & 12 & 1 & 4 & 0.92 \\
\hline & 36 & $\begin{array}{l}\text { Project management process involves strong monitoring and control over activities } \\
\text { on an ongoing basis }\end{array}$ & 13 & 3 & 1 & 0.81 \\
\hline \multirow{6}{*}{ 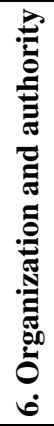 } & 37 & Project managers are given the necessary authority to excute their responsibilities & 16 & 0 & 1 & 1.00 \\
\hline & 38 & There are clearly laid down decision-making principles & 16 & 0 & 1 & 1.00 \\
\hline & 39 & Project team members understand their project responsibilities & 17 & 0 & 0 & 1.00 \\
\hline & 40 & Project managers are held accountable for meeting their responsibilities & 17 & 0 & 0 & 1.00 \\
\hline & 41 & Project teams are generally effectively structured and mobilised & 14 & 1 & 2 & 0.93 \\
\hline & 42 & Decision-making is smooth and efficient & 12 & 3 & 2 & 0.80 \\
\hline \multirow{5}{*}{ 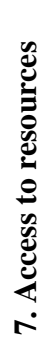 } & 43 & The organization is committed to providing the agreed upon resources & 16 & 0 & 1 & 1.00 \\
\hline & 44 & The organization makes adequate provision for project funding & 16 & 0 & 1 & 1.00 \\
\hline & 45 & $\begin{array}{l}\text { Project managers are adequately empowered to access the required resources for } \\
\text { their projects }\end{array}$ & 16 & 1 & 0 & 0.94 \\
\hline & 46 & $\begin{array}{l}\text { The availability of resources are taken into account when deciding upon projects and } \\
\text { setting priorities }\end{array}$ & 15 & 1 & 1 & 0.94 \\
\hline & 47 & Project managers can normally rely on the work output of organizational resources & 12 & 1 & 4 & 0.92 \\
\hline \multirow{6}{*}{ 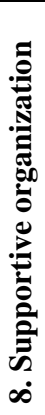 } & 48 & $\begin{array}{l}\text { People from different departments in the organization work together well in project } \\
\text { teams }\end{array}$ & 15 & 0 & 2 & 1.00 \\
\hline & 49 & Top management have an understanding of what project management entails & 15 & 1 & 1 & 0.94 \\
\hline & 50 & $\begin{array}{l}\text { Top management members take active interest in projects and give support when } \\
\text { necessary }\end{array}$ & 15 & 1 & 1 & 0.94 \\
\hline & 51 & $\begin{array}{l}\text { Top management ensure that project priorities are well-defined and are subscribed to } \\
\text { by the rest of the organization }\end{array}$ & 15 & 1 & 1 & 0.94 \\
\hline & 52 & Projects are not seriously affected by conflict existing between departments & 12 & 2 & 3 & 0.86 \\
\hline & 53 & Project work generally is supported by the rest of the organization & 13 & 3 & 1 & 0.81 \\
\hline
\end{tabular}

$\mathrm{N}=17$

Score $=$ Include $/$ (Include + Exclude $)$ 


\begin{tabular}{|c|c|c|c|c|c|c|}
\hline 突 & $\dot{z}$ & Item description & 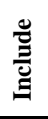 & 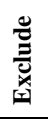 & 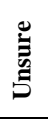 & ڤัँّ \\
\hline \multirow{5}{*}{ 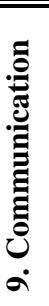 } & 54 & The channels for reporting project problems are clear & 16 & 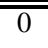 & 1 & 1.00 \\
\hline & 55 & Project information systems provide helpful and accurate project information & 17 & 0 & 0 & 1.00 \\
\hline & 56 & Team members are kept informed of project progress and developments & 16 & 1 & 0 & 0.94 \\
\hline & 57 & Project team members often informally discuss project matters & 11 & 3 & 3 & 0.79 \\
\hline & 58 & Project meetings are usually informative & 9 & 3 & 5 & 0.75 \\
\hline \multirow{4}{*}{ 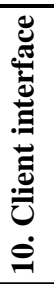 } & 59 & Client or end-user inputs are considered when making project decisions & 16 & 0 & 1 & 1.00 \\
\hline & 60 & Each project has an identified client or end-user & 16 & 1 & 0 & 0.94 \\
\hline & 61 & $\begin{array}{l}\text { During project execution regular discussions are maintained with the client or end- } \\
\text { user }\end{array}$ & 15 & 1 & 1 & 0.94 \\
\hline & 62 & There are normally good relations between project teams and their clients & 12 & 3 & 2 & 0.80 \\
\hline \multirow{4}{*}{ 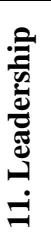 } & 63 & Care is taken to put competent project managers in charge of projects & 17 & 0 & 0 & 1.00 \\
\hline & 64 & Project managers have suitable team and people leadership qualities & 17 & 0 & 0 & 1.00 \\
\hline & 65 & The organization takes adequate steps to appropriately train project managers & 13 & 1 & 3 & 0.93 \\
\hline & 66 & The organization has a core of experienced project managers & 10 & 4 & 3 & 0.71 \\
\hline \multirow{6}{*}{ 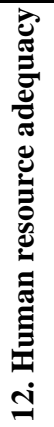 } & 67 & Project team members have adequate teamwork orientation and skills & 14 & 0 & 3 & 1.00 \\
\hline & 68 & Project team members have the maturity to work independently on project tasks & 14 & 1 & 2 & 0.93 \\
\hline & 69 & There is an acceptably low level of rework in most projects & 12 & 1 & 4 & 0.92 \\
\hline & 70 & People participating in projects are generally competent in their fields of expertise & 15 & 2 & 0 & 0.88 \\
\hline & 71 & $\begin{array}{l}\text { There are always enough project team members around with innovative and problem- } \\
\text { solving abilities }\end{array}$ & 11 & 3 & 3 & 0.79 \\
\hline & 72 & Project team members have adequate project management related skills & 10 & 6 & 1 & 0.63 \\
\hline \multirow{6}{*}{ 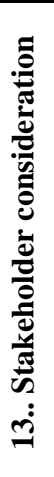 } & 73 & $\begin{array}{l}\text { Project management always consult people that may be affected by projects } \\
\text { (internal and external to the organization) }\end{array}$ & 13 & 1 & 3 & 0.93 \\
\hline & 74 & $\begin{array}{l}\text { Project team members are generally satisfied with participating in projects and how } \\
\text { it contributes to their career growth }\end{array}$ & 13 & 2 & 2 & 0.87 \\
\hline & 75 & Projects are done without disrupting the rest of the organization's workflow & 12 & 2 & 3 & 0.86 \\
\hline & 76 & $\begin{array}{l}\text { Project management is done in harmony with the functioning of line management in } \\
\text { the organization }\end{array}$ & 12 & 2 & 3 & 0.86 \\
\hline & 77 & $\begin{array}{l}\text { Projects are carried out without compromising the culture and values of the } \\
\text { organization }\end{array}$ & 9 & 3 & 5 & 0.75 \\
\hline & 78 & $\begin{array}{l}\text { Project management activities are sensitive to the dominant political sentiments in } \\
\text { the organization }\end{array}$ & 9 & 3 & 5 & 0.75 \\
\hline
\end{tabular}

$\mathrm{N}=17$

Score $=$ Include $/$ (Include + Exclude $)$ 